\title{
Antiradical Activity and Total Phenolics of Algerian Honeys and Antibacterial Effect against Gram-Negative Bacteria
}

\author{
Moussa Ahmed ${ }^{1 *}$, Noureddine Djebli ${ }^{2}$, Saad Aissat ${ }^{1}$, Baghdad Khiati ${ }^{1}$, Meral Ünal ${ }^{3}$ and Salima Bacha ${ }^{1}$ \\ 1 Institute of Veterinary Sciences, Ibn-Khaldoun University, Tiaret, Algeria \\ ${ }^{2}$ Departments of Biology, Faculty of Sciences, Mostaganem University, Algeria \\ ${ }^{3}$ Marmara University, Science and Art Faculty, Department of Biology, Göztepe, 34730 Istanbul, Turkey
}

\begin{abstract}
Six Algerian honeys from different floral origins, were examined for potential antibacterial and antiradical activity. The Folin-Ciocalteu assay was used to measure total phenol content (TPC) and the 2,2-diphenyl-picrylhydrazyl (DPPH) assay was used to determine the scavenging activity of the honey samples. An agar well diffusion assay and spectrophotometric method were used to assess antibacterial activity against two Gram negative strains (Escherichia coli ATCC25922 and Pseudomonas aeruginosa ATCC 50071).Total phenolic content varied from 63.93 to 95.36 $\mathrm{mg} / 100 \mathrm{~g}$ honey as gallic acid equivalent. The DPPH radical scavenging assay was found for an average (30.14 $\% \pm 9.28$ ). The honey samples were found to inhibit all of the tested bacteria. Correlation existed between phenolic content and antiradical activity. Thus Algerian honeys, being a rich source of natural antioxidants, may be used in the prevention of various free radicals related diseases.
\end{abstract}

Keywords: Algerian honeys; Phenolic compounds; DPPH; Antiradical activity; Antibacterial activity

\section{Introduction}

The emergence of resistant Gram negative bacteria presents a major challenge for the antimicrobial therapy of infectious diseases and increases the incidence of mortality and morbidity. Natural products offer an alternative strategy for the discovery of new medications. Honey as most natural products, may have a large variance in therapeutic components depending on its origin. Thus, the floral source of honey plays an important role on its biological properties [1]. Honey ha s been reported to contain about 200 substances (complex mixture of sugars, but also small amounts of other constituents such as minerals, proteins, vitamins, organic acids, flavonoids, phenolic acids, enzymes and other phytochemicals) and is considered to be an important part of traditional medicine [2]. Many authors demonstrated that honey serves as a source of natural antioxidants, which are effective in reducing the risk of heart disease, cancer, immune system decline, different inflammatory processes [3]. The factor contributing to honey antioxidant activity are lysozyme, phenolic acids and flavonoid [4]. The flavonoids in honey are divided into three classes with similar structure: flavonols, flavones and flavonones according to their chemical structure. These are important due to their contribution to honey color, taste and flavour and also due to their beneficial effects on health [5]. Honey is between the Major dietary sources of flavanones, such as Naringenin, which has been shown to possess antioxidant [6], antiproliferative [7], and weakly estrogenic activities in vitro [8]. Chrysin a natural flavone commonly found in honey has been shown to possess an anti-proliferative effect on prostate cancer cells [9]. Quercetin is one of the more representative flavonols in honey [10-12]. The best described property of Quercetin is its ability to act as antioxidant. Quercetin seems to be the most powerful flavonoids for protecting the body against reactive oxygen species, produced during the normal oxygen metabolism or are induced by exogenous damage $[13,14]$.

The phenolic acids are divided in two subclasses: the substituted benzoic acids and cinnamic acids. The actions of flavonoids as immune modulators, radical-scavenging activity, enzyme and hormone action inhibitors are currently of particular interest to medical and nutritionist practitioners and justify the consumption of natural products rich in these phytochemical compounds for their beneficial potential effects [15]. Also the antioxidant activity of honey, however, varies greatly depending on the honey floral source [16]. As well by processing and storage conditions $[17,18]$. Honey has been shown to efficiently inhibit bacterial growth in vitro and in vivo [19]. The antimicrobial properties attributed to honey have been related to both the physical properties of osmosis and the antibacterial properties of hydrogen peroxide levels and the presence of some phytochemicals, mainly phenolic compounds including phenolic acids and flavonoids [20,21]. Numerous in vitro methods are used to evaluate the antioxidant potential of natural products [22-25] for honey antioxidant capacity determination, DPPH radical scavenging assay is a highly accepted method [26-29]. Algeria is characterized by a richness of polliniferous and melliferous resources. Several types of honey are produced in Algeria, where honey production is a traditional practice, well implanted in several regions. [30,31]. The antibacterial properties of Algerian honey have been reported in many studies [32-34]. In this study, the antioxidant activity (scavenging effect on DPPH radicals) and the antibacterial effects of six natural honeys from different floral origin two Gram negative strains Escherichia coli ATCC25922 and Pseudomonas aeruginosa ATCC 50071 were tested by agar well diffusion method and spectrophotometric assay.

\section{Material and Methods}

\section{Honey Samples and their Preparation}

Six honey samples from different sources in Algeria Tiaret (H3, H4, H6); Saida (H1); Relizane (H5), and Mascara (H2). The floral origin

*Corresponding author: Moussa Ahmed, Institute of Veterinary Sciences Ibn-KhaldounTiaret University, Algeria, Tel: + 213 65234059; E-mail: moussa7014@yahoo.fr

Received October 17, 2012; Accepted November 23, 2012; Published November 26, 2012

Citation: Ahmed M, Djebli N, Aissat S, Khiati B, Ünal M, et al. (2012) Antiradica Activity and Total Phenolics of Algerian Honeys and Antibacterial Effect against Gram-Negative Bacteria. J Microb Biochem Technol 4: 152-156. doi:10.4172/19485948.1000087

Copyright: (C) 2012 Ahmed M, et al. This is an open-access article distributed under the terms of the Creative Commons Attribution License, which permits unrestricted use, distribution, and reproduction in any medium, provided the original author and source are credited 
of the samples was specified by microscopic analyses of pollen grains at the laboratory Cari, Louvain-la-Neuve, Belgium. All samples were prepared aseptically and were handled such that they were protected from direct sunlight. Honey samples were stored at $4^{\circ} \mathrm{C}$ in the dark until analyzed.

\section{Antibacterial activity of honey samples}

Honey solutions were prepared in two concentrations: 100 and $50 \%$ (by mass per volume). The samples of each honey (10 g) and sterile water were stored at $37^{\circ} \mathrm{C}$ for 30 min before mixing, to facilitate homogenization. The samples were assayed immediately after dilution. The potential antibacterial activity of six selected natural honeys against two strains of bacteria was studied using the agar well diffusion method and spectrophotometric assay.

\section{Subculturing of test organisms and preparations of the bacterial inoculum}

The test organisms were taken from American Type Culture Collections (ATCC): Two bacterial strains were used for the experiment: E. coli (ATCC 25922) and P. aeruginosa (ATCC 50071). Bacteria were selected for antibacterial activity assay. Cultures were obtained from the Laboratory of Microbiology, Faculty of SE \& SNV, Mostaganem University, Algeria. Stock cultures were maintained on Mueller-Hinton Agar (MHA) at $4^{\circ} \mathrm{C}$. Bacterial inocula were prepared by growing cells in Mueller-Hinton Broth (MHB) for $24 \mathrm{~h}$, at $37^{\circ} \mathrm{C}$. Cell suspensions were diluted in sterile MHB to provide initial cell counts of about $1 \times 10^{6}$ colony-forming units per $\mathrm{ml}(\mathrm{CFU} / \mathrm{ml})$.

\section{Total phenolic content (TPC)}

The total phenolic content was determined by the Folin-Ciocalteu method [35]. Thirty microliters $(\mu \mathrm{l})$ of honey solution $(0.1 \mathrm{~g} / \mathrm{ml})$ was mixed with $2.37 \mathrm{ml}$ of milli Q water and $150 \mu \mathrm{l}$ of $0.2 \mathrm{~N}$ FolinCiocalteu reagents. The solution was thoroughly mixed by vortexing and incubated for $2 \mathrm{~min}$ at ambient temperature. $450 \mu \mathrm{l}$ of sodium carbonate solution $(0.2 \mathrm{~g} / \mathrm{ml})$ was added to the reaction mixture and further incubated for $2 \mathrm{~h}$ at ambient temperature. The absorbance was measured at $765 \mathrm{~nm}$ using a spectrophotometer. The total phenolic content was determined by comparing with a standard curve prepared using gallic acid (0-200 mg/l). The mean of at least three readings was calculated and expressed as mg of gallic acid equivalents (mg GAE)/100 $\mathrm{g}$ of honey.

\section{Determination of antiradical scavenging activity (DPPH)}

The DPPH (2,2-diphenyl-1-picryl-hydrazyl) radical scavenging effect (H/e- transferring ability) of honey samples was measured as per the method described by [36]. The DPPH was dissolved in absolute ethanol to a $0.2 \mathrm{mM}$ concentration. A $100 \mu \mathrm{l}$ aliquot of honey solution $(0.1 \mathrm{~g} / \mathrm{ml})$ was diluted to $500 \mu \mathrm{l}$ with $70 \%$ ethanol, and vigorously mixed with $400 \mu \mathrm{l}$ of DPPH solution by vortexing. The mixture was incubated at room temperature for $15 \mathrm{~min}$ and the absorbance of the solution (T1) was measured at $517 \mathrm{~nm}$. Sample blank (B1) consisted of $600 \mu \mathrm{l}$ of $70 \%$ ethanol and $400 \mu \mathrm{l}$ of DPPH whereas DPPH blank (B2) contained $100 \mu \mathrm{l}$ of honey sample, $500 \mu \mathrm{l}$ of $70 \%$ ethanol and $400 \mu \mathrm{l}$ of absolute ethanol. The DPPH scavenging activity was calculated using the following formula:

$$
\text { DPPH scavenging activity }(\%)=\frac{1-\left(\mathrm{T}_{1}-\mathrm{B}_{2}\right)}{\mathrm{B}_{1}} \times 100
$$

where $\mathrm{T} 1, \mathrm{~B} 1$, and $\mathrm{B} 2$ are the absorbencies of the sample, sample blank and DPPH blank, respectively.

\section{Well diffusion assay}

The activity of six stingless bee honeys was assessed against two reference strains $P$. aerogenosa ATCC 50071 and E. coli ATCC 25922 using an agar well diffusion assay. Briefly, agar plates $(90 \mathrm{~mm})$ containing $20 \mathrm{ml}$ of MHA were inoculated using a swab from a suspension of each organism containing c. $1 \times 10^{6} \mathrm{CFU} \mathrm{ml}^{-1}$. An 8 -mm diameter well was cut into the agar and $100 \mu \mathrm{l}$ of 50 and $100 \%$ honey solution (w/v,) prepared in sterile distilled water) was aliquoted into the well. The controls were set up with equivalent quantities of water as controls. The plates were incubated at $35 \pm 2^{\circ} \mathrm{C}$ for 24 hours. Zones of inhibition were measured using a Vernier caliper (Draper). The antibacterial potential of test compound was determined on the basis of mean diameter of zone of inhibition around the wells in millimeters. Each assay was performed in duplicate and repeated twice. The antibacterial activity was classified as: no sensitive, for diameters lower than $8 \mathrm{~mm}$; sensitive, for diameters from 8 to $14 \mathrm{~mm}$; very sensitive, for diameters from 15 to $19 \mathrm{~mm}$; extremely sensitive, for diameters higher than $20 \mathrm{~mm}$.

\section{Spectrophotometric assay}

The absorbance readings obtained from the dose-response curve were used to construct growth inhibition profiles using the following formula:

$$
\% \text { growthinhibition }=\frac{\mathrm{A}_{\text {control }}-\mathrm{A}_{\text {experimental }}}{\mathrm{A} \text { control }} \times 100
$$

\section{Statistical analysis}

All analyses were carried out in triplicate and the data were expressed as means \pm standard deviations (SD).Statistical analyses were performed using the software Statistica 8.0 (Stat Soft). Differences between means at the $95 \%(\mathrm{p}<0.05)$ confidence level were considered statistically significant. Correlations were obtained by Pearson's correlation coefficient ( $\mathrm{r}$ ) in bivariate linear correlations.

\section{Results and Discussion}

\section{The total phenolic content (TPC)}

Polyphenols are an important group of compounds regarding the appearance and the functional properties of honey. They are members of a class of natural compounds, recently considered of high scientific and therapeutic interest. In the long human tradition, honey has been used not only as a nutrient but also as a medicine [37]. TPC of the different monofloral and unifloral honeys was investigated by the Folin-Ciocalteu assay and the mean values and standard deviation are shown in table 1 . The total phenolic content (mg GAE/100 g of honey) of Algerian honeys was found in the range of 63.93 to 95.36 , which was determined using gallic acid as standard $\left(\mathrm{R}^{2}=0.9988\right)$ table 1 . The total phenolic content of certain honey samples has been previously

\begin{tabular}{|c|c|c|}
\hline Honey & $\begin{array}{c}\text { Total polyphenol } \\
\text { Content } \\
(\mathrm{mg} / 100 \mathrm{~g} \pm \mathrm{SD})^{*}\end{array}$ & $\begin{array}{c}\text { DPPH scavenging activity } \\
(\% \pm \mathrm{SD})^{*}\end{array}$ \\
\hline H1 & $85.62 \pm 2.75$ & $26.93 \pm 3.22$ \\
H2 & $95.36 \pm 6.08$ & $22.49 \pm 11.71$ \\
H3 & $82.85 \pm 14.24$ & $29.76 \pm 5.36$ \\
H4 & $65.31 \pm 1.60$ & $42.65 \pm 22.34$ \\
H5 & $64.29 \pm 1.55$ & $28.95 \pm 464$ \\
\hline Mean & $63.93 \pm 0.11$ & $30.11 \pm 8.45$ \\
\hline
\end{tabular}

*Values are means of triplicate determinations.

DPPH (2. 2-diphenyl-1-picryl-hydrazyl)

Table 1: Total polyphenol content and DPPH scavenging activity of tested honeys. 
determined [38-40] for example Meda et al. [41] reported that total phenols of Burkina Fasan honey were 32.59-114.75 mg GAE/100 g. A similar level of phenolic content was also observed for Romanian honeydew honeys for which the phenolic content varied from 23.0 to $125.0 \mathrm{mg}$ GAE/ $100 \mathrm{~g}$ [42]. For Indian and Croatian honeys, the phenolic content ranged from 48 to 99 and 31.72 to $80.11 \mathrm{mg}$ GAE/ 100 g, respectively $[43,44]$.

\section{DPPH scavenging activity}

The radical scavenging effects of Algerian honey were tested using methanolic solution of the DPPH free radical which exhibits a deep purple colour with maximum absorption at $517 \mathrm{~nm}$. The DPPH free radical has the advantage of being unaffected by certain side reactions, such as metal ion chelation and enzyme inhibition [45]. The results obtained for DPPH radical scavenging activity of these honeys are summarized in table 1 . The percentage DPPH scavenging activity ranged from $(22.49 \pm 11.71) \%$ to $(42.65 \pm 22.34) \%$. table1. These values are similar to $23.81 \%-100 \%$ as reported by Wilczyńskal [46] for Polish honey respectively. The activity was also within a lower range of $2.30 \%$ and $90.73 \%$ reported for Turkish honey [47].

\section{Correlation between the polyphenol contents and antiradical activity}

The correlation between DPPH activities and total polyphenol contents in 6 honey samples are analyzed in this study and the results are presented in figure 1. The coefficients of correlation between the total phenolic content of six honeys and values obtained with DPPH scavenging activity were calculated.

\section{Inhibitory activity evaluation}

The antibacterial activity of the 6 honey samples was first measured by agar well diffusion and spectrophotometric method, which is suitable for a previous screening test. In the antibacterial screening, solutions with different percentage of honey were used in the assay. The presence and diameter of zones of inhibition are dependent on the honey concentrations. Figure 2 and 3the inhibitory capacity of honeys of the same botanical origin is variable and the honey effect on the growth of both microorganisms could be different figure 4 and 5

Antibacterial activities of the honey samples with $50 \%$ concentration against $P$. auregenosa and E. coli strains are presented in figure 2 and 3 . The inhibition zones of honey samples varied from (23-40) $\mathrm{mm}$ by P. auregenosa to (29-35) $\mathrm{mm}$ by E .coli. Antibacterial

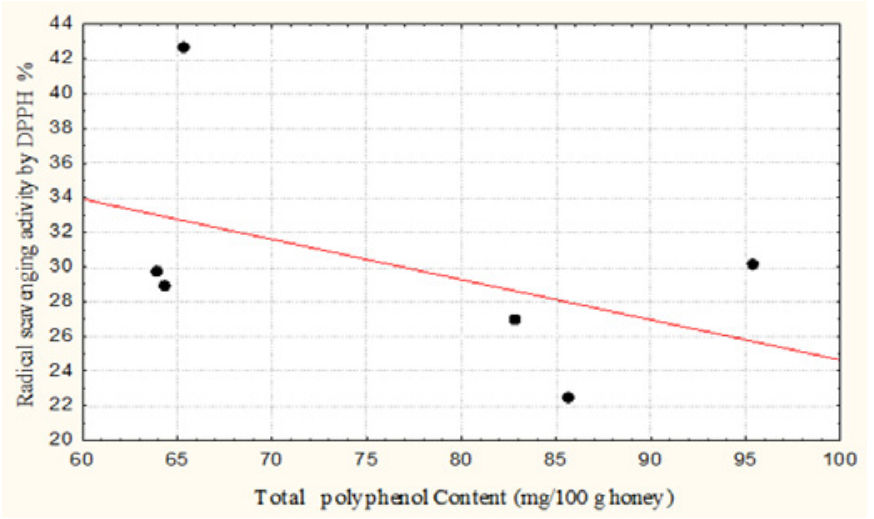

Figure 1: Correlation between DPPH values and total polyphenol contents in honey samples $\left(R^{2}=0.414, p<0.05\right)$.

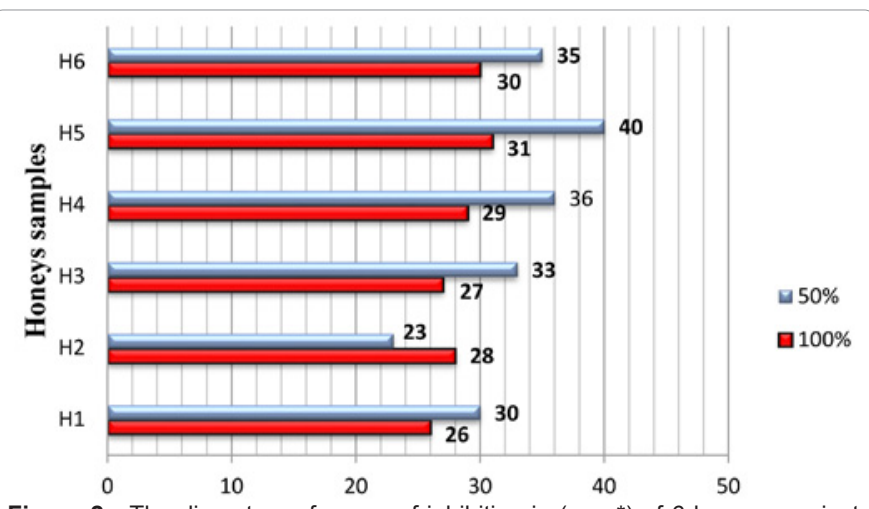

Figure 2: The diameters of zones of inhibition in $\left(\mathrm{mm}^{*}\right)$ of 6 honeys against $P$. auregenosa ATCC 50071 Tiaret $(\mathrm{H} 3, \mathrm{H} 4, \mathrm{H} 6)$; Saida $(\mathrm{H} 1)$; Relizane $(\mathrm{H} 5)$; Mascara (H2)

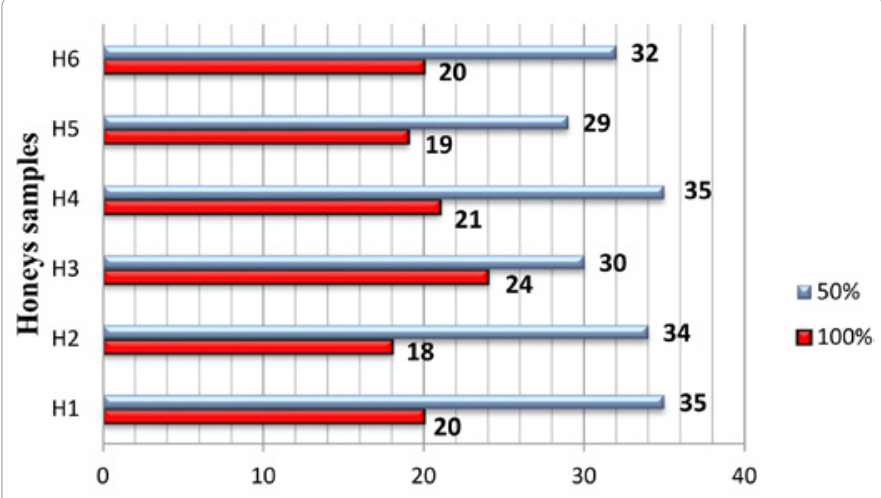

Figure 3: The diameters of zones of inhibition in $\left(\mathrm{mm}^{*}\right)$ of 6 honeys aigainst E.coli ATCC 25922 Tiaret (H3, H4,H6); Saida (H1);Relizane (H5);Mascara ..

activities of the honey samples with $100 \%$ concentration against P. auregenosa and E.coli strains are presented in Figure 2 and 3. The inhibition zones of honey samples varied from (26-31) $\mathrm{mm}$ by $P$. auregenosa to (18-24) $\mathrm{mm}$ by E. coli. The growth inhibition profiles of natural honeys are presented in Figure 4 and 5. A variation in the antibacterial activity with floral source was observed at 50 and $100 \%$ concentration, some inhibitory effect was observed on all pathogens. Honey has a broad spectrum of bactericidal and bacteriostatic activities $[48,49]$. Several bioactive compounds have been identified in honey which contributed to its antibacterial action. The antibacterial property of honey is dependent on several contributing factors. Low water content, high osmolarity (high sugar content), low $\mathrm{pH}$, antibiotic peptides, methylglyoxal, catalase to hydrogen-peroxide ratio, Maillard reaction products, bee defensin-1, production of hydrogen peroxide, although involved in antibacterial action, are common properties for all honeys and could not explain the variability in activity between honeys. From surveys of antibacterial activity in different honeys, it became clear that a phytochemical composition of honeys was responsible for the degree of bacteriostatic and bactericidal action [50-59]. Phenolic compounds originating from plant nectar have been proposed as important factors for the no peroxide antibacterial activity of honey [60]. Several antibacterial phenolic compounds have been identified in honeys [61-63]. Davidson et al. [64] have shown that individual phenolic compounds have growth inhibition on a wide range of Grampositive and Gram-negative bacteria. In a recent study Ahmed et al. [33] reported that E. coli is more sensitive to the action of honey than $P$. aeruginosa. The results of this study clearly show that honey has the 
Citation: Ahmed M, Djebli N, Aissat S, Khiati B, Ünal M, et al. (2012) Antiradical Activity and Total Phenolics of Algerian Honeys and Antibacterial Effect against Gram-Negative Bacteria. J Microb Biochem Technol 4: 152-156. doi:10.4172/1948-5948.1000087

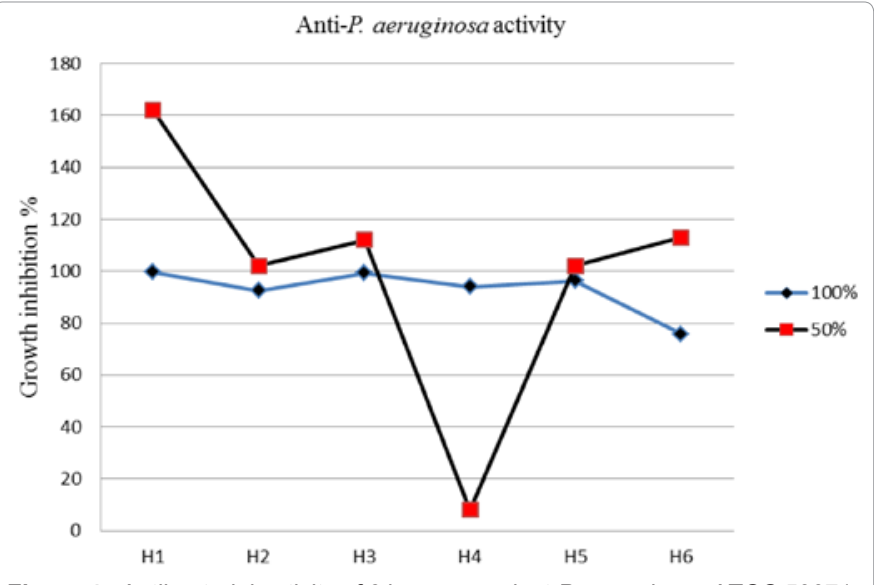

Figure 4: Antibacterial activity of 6 honeys against $P$. aeruginosa ATCC 50071.

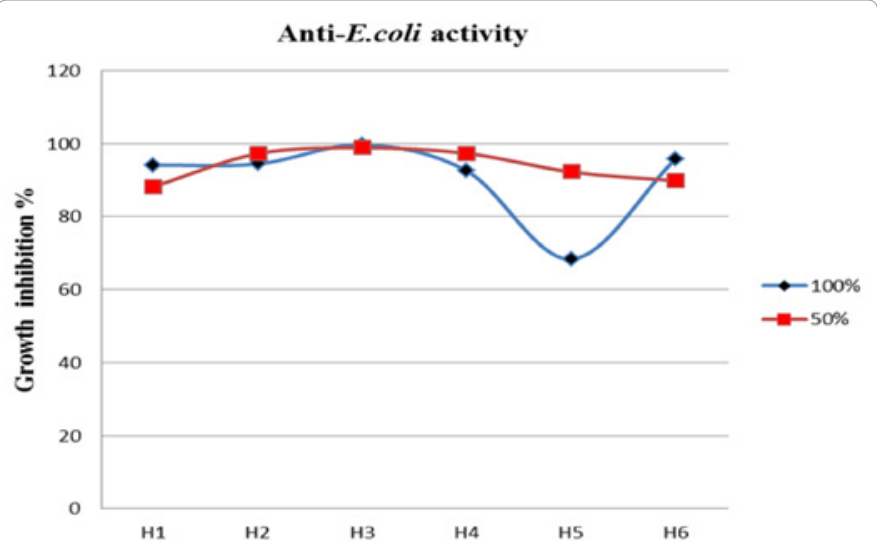

Figure 5: Antibacterial activity of 6 honeys against E. coli ATCC 25922.

potential to be used as an antibacterial agent to prevent and control infection with gram-negative bacteria.

\section{Conclusions}

This study gave an overview on the antibacterial activity of honey from Algeria and showed that many honeys have potential for therapeutic use as antibacterial agents. Phenolic compounds play a major role in the antibacterial activity of honey and the differences between honey samples in terms of antibacterial and antioxidant activity could be attributed to the natural variations in floral sources of nectar and the different locations. The results obtained, in the inhibitory activity assays, show that the spectrophotometric method is an easy and useful tool in the evaluation of the antibacterial capacity of honeys against $P$. aeruginosa and $E$. coli.

Nevertheless, further studies including other bacterial strains are necessary in order to confirm the utility of this technique for the evaluation of the non-peroxidic antibacterial activities of Algerian honeys.

\section{Acknowledgments}

Authors are thankful to staff of Mostaganem University for providing material.

\section{References}

1. Molan PC (2002) Not all honeys are the same for wound healing. Bulletin of the European Tissue Repair Society 9: 5-6.

2. White JW (1979) Composition of honey. Honey: A comprehensive survey
London: Heinemann 157-158

3. The national honey board (2003) Honey - Health and therapeutic qualities.

4. Snowdon JA. Cliver DO (1996) Microorganisms in honey [J]. Internat J Food Microbiol 31: 1-26.

5. Devarajan S, Venugopal S (2012) Antioxidant anda-amylase inhibition activities of phenolic compounds in the extracts of Indian honey. CJNM 10: 0255-0259.

6. Wang W, Goodman MT (1999) Antioxidant property of dietary phenolic agents in a human LDL-oxidation ex vivo model: interaction of protein binding activity. Nutr Res 19: 191-202.

7. Manthey JA, Guthrie N (2002) Antiproliferative activities of citrus flavonoids against six human cancer cell lines. Journal of Agricultural and Food Chemistry 50: $5837-5843$.

8. Miksicek RJ (1993) Commonly occurring plant flavonoids have estrogenic activity. Mol Pharmacol 44: 37-43.

9. Samarghandian S, Afshari JT, Davoodi S (2011) Chrysin reduces proliferation and induces apoptosis in the human prostate cancer cell line pc-3. Clinics 66 1073-1079.

10. Tomas-Barberan F, Espín JC (2001) Phenolic compounds and related enzymes as determinants of quality in fruits and vegetables. J Sci Food Agric 81: 853-876.

11. Soler C, Gil MI, Garcia-Viguera C, Tomas-Barberan FA (1995) Flavonoid patterns of French honeys with different floral origin. Apidologie 26: 53-60.

12. Michalkiewicz A, Biesaga M, Pyrzynska K (2008) Solidphase extraction procedure for determination of phenolic acids and some flavonols in honey. Journal of Chromatography A 1187: 18-24.

13. De Groot H (1994) Reactive oxygen species in tissue injury Hepatogastroentrology 41: 328-332.

14. Grace PA (1994) Ischaemia-reperfusion injury. Br J surg 81: 637-647.

15. Havsteen BH (2002) The biochemistry and medical significance of the flavonoids. Pharmacol Ther 96: 67-202.

16. Gheldof N, Engeseth NJ (2002) Antioxidant capacity of honeys from various floral sources based on the determination of oxygen radical absorbance capacity and inhibition of in vitro lipoprotein oxidation in human serum samples. J Agric Food Chem 50: 3050-3055.

17. Wang XH, Gheldof N, Engeseth NJ (2004) Effect of processing and storage on antioxidant capacity of honey. J Food Sci 69: 96-101.

18. Antony SM, Han IY, Rieck JR, Dawson PL (2000) Antioxidative effect of Maillard reaction products formed from honey at different reaction times. J Agric Food Chem 48: 3985-3989.

19. Brudzynski K, Kim L (2011) Storage-induced chemical changes in active components of honey de-regulate its antibacterial activity. Food Chem 126: 1155-1163.

20. Taormina PJ, Niemira BA, Beuchat LR (2001) Inhibitory activity of honey against foodborne pathogens as influenced by the presence of hydrogen peroxide and level of antioxidant power. Int J Food Microbiol 69: 217-225.

21. Weston RJ, Brocklebank LK, Lu Y (2000) Identification and quantitative levels of antibacterial components of some New Zealand honeys. Food Chem 70: 427-435.

22. Snow MJ, Manley-Harris M (2004) On the nature of non-peroxide antibacterial activity in New Zealand manuka honey. Food Chem 84: 145-147.

23. Aljadi AM, Kamaruddin MY (2002) Evaluation of the phenolic contents and antioxidant capacities of two Malaysian floral honeys. Food Chem 85: 513-518.

24. Jerković I, Marijanović Z (2010) O Oak (Quercus frainetto Ten.) Honeydew Honey-Approach to Screening of Volatile Organic Composition and Antioxidant Capacity (DPPH and FRAP Assay). Molecules 15: 3744-3756.

25. Frankel S, Robinson GE, Berenbaum MR (1998) Antioxidant capacity and correlated characteristic of 14 unifloral honeys. J Apicultural Res 37: 27-31.

26. Serem JC, Bester MJ (2012) Physicochemical properties, antioxidant activity and cellular protective effects of honeys from southern Africa. Food Chem 133 1544-1550. 
Citation: Ahmed M, Djebli N, Aissat S, Khiati B, Ünal M, et al. (2012) Antiradical Activity and Total Phenolics of Algerian Honeys and Antibacterial Effect against Gram-Negative Bacteria. J Microb Biochem Technol 4: 152-156. doi:10.4172/1948-5948.1000087

27. Lachman J, Orsák M, Hejtmánková A, Kovářova E (2010) Evaluation of antioxidant activity and total phenolics of selected Czech honeys. LWT-Food Sci Technol 43: 52-58

28. Peréz RAM, Hortigüela LV, Lozano PL, Rojo Cortina MD, Carretero CL (2008) In Vitro Antioxidant and Antimicrobial Activities of Spanish Honeys. Int J Food Prop 11: 727-737.

29. McKibben J, Engeseth NJ (2002) Honey as a protective agent against lipid oxidation in ground Turkey. J Agric Food Chem 50: 592-595.

30. Ahmed M, Djebli N, Aissat S, Meslem AM, Bacha S (2012) The Influence of Botanical Origin and Physicochemical Parameters on the Antifungal Activity of Algerian Honey. J Plant Pathol Microb 3: 5.

31. Ouchemoukh S, Schweizer P, Bachir Bey M, Djoudad-Kadji H, Louaileche H (2010) HPLC sugar profiles of Algerian honeys. Food Chem 121: 561-568.

32. Ahmed M, Djebli N, Meslem AM, Aissat S (2012) Antibacterial activity of various honey types of Algeria against Pathogenic Gram-Positive cocci: Staphylococcus aureus and Streptococcus pyogenes. Asian Pac J Tro Med 773-776.

33. Ahmed M, Djebli N, Meslem AM, Aissat S (2012) Antibacterial activity of various honey types of Algeria against Pathogenic Gram-Negative Bacilli: Escherichia coli and Pseudomonas aeruginosa. Asian Pac J Trop Disease 2: 211-214.

34. Ahmed M, Aissat S, Djebli N, Boulkaboul A, Meslem AM, et al. (2011) The Influence of Starch of Ginger on the Antibacterial Activity of Honey of Different Types from Algeria against Escherichia coli and Staphylococcus aureus. IJMR 2: 258-262.

35. Singleton VL, Orthofer R, Lamuela-Raventos RM (1999) Analysis of total phenols and other oxidation substrates and antioxidants by means of FolinCiocalteu reagent. Methods Enzymol 299: 152-178.

36. Chen HY, Lin YC, Hsieh CL (2007) Evaluation of antioxidant activity of aqueous extract of some selected nutraceutical herbs. Food Chem 104: 1418-1424.

37. Alvarez-Suarez JM, Tulipani S, Diaz D, Estevez Y, Romandini S, et al. (2010) Antioxidant and antimicrobial capacity of several monofloral Cuban honeys and their correlation with color, polyphenol content and other chemical compounds. Food Chem Toxicol 48: 2490-2499.

38. Khalil MI, Alam N, Moniruzzaman M, Sulaiman SA, Gan SH (2011) Phenolic Acid Composition and Antioxidant Properties of Malaysian Honeys. J Food Sci 76: 921-928.

39. Brudzynski K, Miotto D (2011) The relationship between the content of Maillard reaction-like products and bioactivity of Canadian honeys. Food Chem 124: 869-874

40. Islam A, Khalil I, Islam N, Moniruzzaman M, Mottalib A, et al. (2012) Physicochemical and antioxidant properties of Bangladeshi honeys stored for more than one year. BMC Complementary and Alternative Medicine 12: 177.

41. Meda A, Lamien CE, Romito M, Millogo J, Nacoulma OG (2005) Determination of the total phenolic, flavonoid and proline contents in Burkina Fasan honey, as well as their radical scavenging activity. Food Chem 91: 571-577.

42. Al ML, Daniel D, Moise A, Bobis O, Laslo L, et al. (2009) Physico-chemical and bioactive properties of different floral origin honeys from Romania. Food Chem 112: 863-867.

43. Saxena S, Gautam S, Sharma A (2010) Physical, biochemical and antioxidant properties of some Indian honeys. Food Chem 118: 391-397.

44. Krpan M, Marković K, Šarić G, Skoko B, Hruškar M, et al. (2009) Antioxidant activities and total phenolics af acacia honey. Czech J Food Sci 27: S245-S247.

45. Amorowicz R, Pegg RB, Rahimi-Moghaddam P, Barl B, Weil JA (2004) Freeradical scavenging capacity and antioxidant activity of selected plant species from the Canadian prairies. Food Chem 84: 551-562.

46. Wilczyńska A (2010) Phenolic content and antioxidant activity of different types of polish honey - short report. Pol J Food Nutr Sci 60: 4: 309-313.

47. Silici S, Sagdic O, Ekici L (2010) Total phenolic content, antiradical, antioxidant and antimicrobial activities of Rhododendron honeys. Food Chem 121: 238243.

48. Dong R, Zheng Y, Xu B (2011) Phenolic Profiles and Antioxidant Capacities of Chinese Unifloral Honeys from Different Botanical and Geographical Sources. Food Bioprocess Technol.
49. Molan PC (2002) Re-introducing honey in the management of wounds and ulcers - theory and practice. Ostomy Wound Manage 48: 28-40.

50. Allen KL, Molan PC, Reid GM (1991) A survey of the antibacterial activity of some New Zealand honeys. J Pharm Pharmacol 43: 817-822.

51. Ceyhan N, Ugur A (2001) Investigation of in vitro antimicrobia activity of honey. Riv Biol 94: 363-371.

52. Lusby PE, Coombes AL, Wilkinson JM (2005) Bactericidal activity of different honeys against pathogenic bacteria. Arch Med Res 36: 464-467.

53. Mundo MA, Padilla-Zakour OI, Worobo RW (2004) Growth inhibition of foodborne pathogens and food spoilage organisms by select raw honeys. Int $J$ Food Microbiol 97: 1-8.

54. Wilkinson JM, Cavanagh HM (2005) Antibacterial activity of 13 honeys against Escherichia coli and Pseudomonas aeruginosa. J Med Food 8: 100-103.

55. Aljadi AM, Yusoff K (2003) Isolation and identification of phenolic acids in Malaysian honey with antibacterial properties. Turk J Med Sci 33: 229-236.

56. Kwakman PH, de Boer L, Ruyter-Spira CP, Creemers-Molenaar T, Helsper JP, et al. (2011) Medical-grade honey enriched with antimicrobial peptides has enhanced activity against antibiotic-resistant pathogens. Eur J Clin Microbio Infect Dis 30: 251-257.

57. Adams CJ, Boult CH, Deadman BJ, Farr JM, Grainger MN, et al. (2008) Isolation by HPLC and characterisation of the bioactive fraction of New Zealand manuka (Leptospermum scoparium) honey. Carbohydr Res 343: 651-659.

58. Weston RJ (2000) The contribution of catalase and other natural products to the antibacterial activity of honey: A review. Food Chem 71: 235-239.

59. Mavric E, Wittmann S, Barth G, Henle T (2008) Identification and quantification of methylglyoxal as the dominant antibacterial constituent of Manuka (Leptospermum scoparium) honeys from New Zealand. Mol Nutr Food Res 52: 483-489.

60. Kwakman PH, Zaat SA (2012) Antibacterial Components of Honey. IUBMB Life 64: 48-55.

61. Russell KM, Molan PC, Wilkins AL, Holland PT (1990) Identification of some antibacterial constituents of New-Zealand Manuka honey. J Agric Food Chem 38: 10-13.

62. Weston RJ, Brocklebank LK, Lu YR (2000) Identification and quantitative levels of antibacterial components of some New Zealand honeys. Food Chem 70 427-435.

63. Isla MI, Craig A, Ordonez R, Zampini C, Sayago J, et al. (2011) Physico chemical and bioactive properties of honeys from Northwestern Argentina. LWT-Food Sci Technol 44: 1922-1930.

64. Davidson PM, Sofos JN, Brenem AL (2005) Antimicrobials in Foods. (3rdedn), Marcel Dekker Inc, New York, USA. 